\title{
Molecular Cloning of the Plasmid-located Determinants for CS1 and CS2 Fimbriae of Enterotoxigenic Escherichia coli of Serotype O6:K15:H16 of Human Origin
}

\author{
By MAIRE BOYLAN, ${ }^{1,2}+$ DAVID C. COLEMAN, ' JUNE R. SCOTT ${ }^{2}$ AND \\ CYRIL J. SMYTH ${ }^{1 *}$ \\ 'Department of Microbiology, Moyne Institute, Trinity College, Dublin 2, Republic of Ireland \\ ${ }^{2}$ Department of Microbiology and Immunology, Emory University School of Medicine, Atlanta, \\ GA 30322, USA
}

(Received 17 March 1987; revised 3 May 1988)

\begin{abstract}
The plasmid pCS001, isolated from an enterotoxigenic strain of Escherichia coli, mediates expression of the CS1 or CS2 and CS3 fimbrial adhesins in appropriate $E$. coli hosts. To characterize this further, HindIII-generated DNA fragments of this plasmid were cloned into the vector plasmid pBR322. A chimaera, called pCS200, which mediated expression of the CS1 or CS2 fimbrial antigen but not of CS3 fimbrial antigen in appropriate host strains, was obtained. The DNA inserted into the vector sequences of plasmid pCS200 comprised HindIII fragments of $4.7 \mathrm{kbp}$ and $0.8 \mathrm{kbp}$. Plasmid pCS200-carrying wild-type $E$. coli hosts of serotype O6:K15:H16 that expressed the CS1 or CS2 antigen also caused mannose-resistant agglutination of bovine red blood cells, suggesting that functional fimbriae were present on the bacterial surface. As previously observed with strain K 12 recipients of CS-fimbriae-associated plasmids mobilized from wild-type enterotoxigenic $E$. coli, K12 recipients of the chimaeric plasmid pCS200 did not express the CS1 or CS2 fimbrial antigen. An oligonucleotide probe, synthesized on the basis of the published $\mathrm{N}$-terminal amino acid sequence of the CS2 fimbrial subunit, hybridized to plasmid pCS200, indicating that the gene for the structural subunit of this fimbria resided on the plasmid.
\end{abstract}

\section{INTRODUCTION}

Enterotoxigenic strains of Escherichia coli (ETEC) of human origin possessing fimbrial adhesins on their cell surfaces which promote attachment of these bacteria to small intestinal enterocytes belong to a relatively small number of serogroups (Jones \& Isaacson, 1984; Klemm, 1985; Parry \& Rooke, 1985; Smyth, 1986; de Graaf \& Mooi, 1986; Levine, 1987). One of these adhesins, termed colonization-factor antigen II (CFA/II), was originally described as a single fimbrial antigen (Evans \& Evans, 1978), but was subsequently shown to consist of three immunologically distinct fimbriae termed CS1, CS2 and CS3 (Cravioto et al., 1982; Smyth, 1982, 1984, 1986; Mullany et al., 1983; Levine et al., 1984). Expression of CS1 or CS2 fimbriae correlates with the biotype of certain O-serovar 6 strains (Scotland et al., 1977). CS1 fimbriae are produced by ETEC of serotype $\mathrm{O} 6: \mathrm{K} 15: \mathrm{H} 16$ or $\mathrm{H}$ - of biotype A, whereas CS2 fimbriae are expressed by ETEC of the same serotype but of biotypes B, C and F (Smyth, 1986). CS3 fimbriae are produced by most serotype $06: \mathrm{K} 15: \mathrm{H} 16$ or $\mathrm{H}^{-}$strains in addition to CS1 or CS2 fimbriae, although a rare CS2-fimbriae-only phenotype has been reported (Cravioto et al., 1982; Smyth,

+ Present address: Department of Biochemistry, Emory University School of Medicine, Atlanta, GA 30322, USA.

Abbreviations: CS fimbriae (antigen), Coli surface-associated fimbriae (antigen); CFA/II, colonization-factor antigen II; ETEC, enterotoxigenic $E$. coli; ST, heat-stable enterotoxin. 
1982). With the exception of one strain of serotype $\mathrm{O} 139: \mathrm{H} 28$, which produced CS 1 and CS3 fimbriae (Scotland et al., 1985), only CS3 fimbriae are expressed by CFA/II ${ }^{+}$ETEC strains belonging to $\mathrm{O}$-serovars other than $\mathrm{O6}$.

Expression of CS1, CS2 and CS3 fimbriae has been associated with the presence in CFA/II ${ }^{+}$ ETEC strains of single non-conjugative plasmids ranging in molecular mass from 50 to 115 MDa (Mullany et al., 1983; Smith et al., 1983; Boylan \& Smyth, 1985; Scotland et al., 1985; Echeverria et al., 1986). CS-fimbriae-associated plasmids have been transferred to various $E$. coli hosts by mobilization from serotype O6:K15:H16 ETEC strains of biotypes A, B, C and F, and from several ETEC strains of different serotypes expressing only CS3 fimbriae (Mullany $e t$ al., 1983; Smith et al., 1983; Boylan \& Smyth, 1985; Scotland et al., 1985). Irrespective of their origin, introduction of these plasmids into $E$. coli strain $\mathrm{K} 12$ recipients and into wild-type CSfimbriae-negative (CS-Fim ${ }^{-}$) variants of ETEC of serotypes other than $\mathrm{O6}: \mathrm{K} 15: \mathrm{H} 16$ or $\mathrm{H}$ resulted in expression of only CS3 fimbriae (Mullany et al., 1983; Boylan \& Smyth, 1985; Scotland et al., 1985). Mobilization of the plasmids into a number of O-serovar 6 strains of various serotypes other than serotype O6:K15:H16 also conferred a CS3-fimbriae-only phenotype on recipients (Mullany et al., 1983; Boylan \& Smyth, 1985). With the exception of one ETEC strain of serotype 0139:H28 (Scotland et al., 1985), CS1 or CS2 fimbriae were only detected when the CS-fimbriae-associated plasmids were transferred into CS-Fim ${ }^{-}$ETEC strains of serotype $\mathrm{O} 6: \mathrm{K} 15: \mathrm{H} 16$ or $\mathrm{H}-$. Thus, in addition to plasmid-determined functions, certain as yet undefined properties of the host strain appear to be necessary for expression of $\mathrm{CS} 1$ and CS2 fimbriae to occur.

The haemagglutination assay has frequently been used as a model for bacterial adhesion (Duguid \& Old, 1980; Old, 1985). ETEC possessing the CS1, CS2 and CS3 fimbrial antigens cause mannose-resistant haemagglutination of bovine red blood cells (Evans \& Evans, 1978; Smyth, 1982; Cravioto et al., 1982). CS1 and CS2 fimbriae possess a rigid rod-shaped morphology and have a diameter of $7 \mathrm{~nm}$, whereas CS3 fimbriae are thin wiry structures of diameter 2-4 nm (Mullany et al., 1983; Smyth, 1984; Levine et al., 1984). They are composed of subunits of 16.5, 15.3 and 15.0 kDa, respectively (Smyth, 1982; Levine et al., 1984; Boylan et al., 1987). Occasionally, purified CS3 fimbriae reveal two distinct polypeptide bands (Levine et al., 1984).

The host-strain-associated expression of CS1, CS2 and CS3 fimbriae is unique among the ETEC fimbrial systems studied (Klemm, 1985; Smyth, 1986; de Graaf \& Mooi, 1986). Several hypotheses to explain this phenomenon have been proposed (Smyth, 1986; Boylan, 1987). Molecular cloning of the genetic determinants involved in the expression of CS1, CS2 and CS3 fimbriae was begun with the long-term objective of studying the regulation of their expression separately in different hosts (Eisenstein \& Engleberg, 1986). The genetic determinant encoding CS3 fimbriae has been cloned and characterized and the gene for the structural subunit shown to be plasmid located (Manning et al., 1985; Boylan et al., 1987). The aim of the present study was to obtain by molecular cloning the plasmid-located determinants associated with expression of CS1 and CS2 fimbriae.

\section{METHODS}

Bacterial strains, plasmids and culture conditions. The bacterial strains used are listed in Table 1. Strains were routinely grown at $37^{\circ} \mathrm{C}$ on L-agar or in L-broth without glucose (Lennox, 1955). When required, CFA agar was employed in order to favour expression of CS fimbrial antigens (Evans et al., 1977). The plasmid pCS001, which was used as the source of target DNA in cloning experiments, has been described previously (Boylan \& Smyth, 1985; Boylan et al., 1987). The $E$. coli plasmid pBR322 was used as the cloning vector (Bolivar et al., 1977).

Enzymes and chemicals. Restriction endonucleases, T4 DNA ligase, T4 polynucleotide kinase and alkaline phosphatase were purchased from Boehringer or New England Biolabs and were used according to the manufacturer's specifications. Swine anti-rabbit immunoglobulin-horseradish peroxidase conjugate was from Dakopatts A/S, Copenhagen, Denmark. $\left[\gamma^{-32} \mathrm{P}\right] \mathrm{ATP}\left(3000 \mathrm{Ci} \mathrm{mmol}{ }^{-1} ; \sim 110 \mathrm{TBq} \mathrm{mmol}^{-1}\right)$ and $\left[{ }^{35}\right.$ S $]$ methionine $\left(>1000 \mathrm{Ci} \mathrm{mmol}^{-1}\right.$; $>37 \mathrm{TBq} \mathrm{mmol}{ }^{-1}$ ) were obtained from Amersham. Antibiotics (Sigma) were used at the following concentrations: ampicillin, $100 \mu \mathrm{g} \mathrm{ml}^{-1}$; rifampicin, $100 \mu \mathrm{g} \mathrm{ml}^{-1}$; tetracycline, $10 \mu \mathrm{g} \mathrm{ml}^{-1}$.

DNA techniques. Plasmid pCS001 DNA was prepared by the method of Hansen \& Olsen (1978). Plasmid DNA from $E$. coli strains carrying the vector plasmid pBR322 or its recombinant derivatives was prepared from cleared lysates by centrifugation in ethidium bromide/caesium chloride gradients as described by Clewell \& Helinski 
Table 1. E. coli strains and plasmids used in molecular cloning of CS1-and CS2-fimbrialantigen-associated determinants

Strain/

plasmid Genotype/phenotype/serotype*

Comments*

Reference(s)

C600 lac hspH hspR leu supE thi thr tonA $\mathrm{K} 12$ derivative

DS410 ara lacY malA $\min A \min B \operatorname{mtl} r p s L$ thi Minicell producing strain tonA $x y l$ Azir $^{r}$

ED2030 $\Delta($ lac $) \times 174 \mathrm{gal} \mathrm{his}^{+}$recA56 thi trp $\quad \mathrm{Rec}^{-}$host for transformation

C921b-1 O6:K15:H16, biotype A, $\mathrm{CS}^{+}{ }^{+} \mathrm{CS}^{+}$, Enterotoxigenic diarrhoeal $\mathrm{LT}^{+}, \mathrm{ST}^{+}$ isolate

Appleyard (1954)

Dougan \& Sherratt (1977)

Foster \& Willetts (1976)

Smyth $(1982,1984)$

C921b-2 O6:K15:H16, biotype A, CS1- CS3-, Nonenterotoxigenic; spontaneous Smyth (1982, 1984) Rif $^{r}$, LT $^{-}$, ST $^{-}$

CS-Fim ${ }^{-}$variant of

strain C921b-1

C91f O6:K15:H16, biotype C, CS2 ${ }^{+}$only, Enterotoxigenic diarrhoeal Smyth $(1982,1984)$ $\mathrm{LT}^{+}, \mathrm{ST}^{+} \quad$ isolate

C91f-6 O6:K15:H16; biotype C, CS2- ${ }^{-}$Rif ${ }^{r}$, Nonenterotoxigenic; spontaneous Smyth $(1982,1984)$ $\mathrm{LT}^{-}, \mathrm{ST}$

CS-Fim ${ }^{-}$variant of

strain C91f

pCS001 Amp ${ }^{r}, \mathrm{CS}^{+} \mathrm{CS}^{2}{ }^{+} \mathrm{CS}^{+}, \mathrm{LT}^{+}, \mathrm{ST}^{+}$

CS-fimbriae-associated plasmid mobilized from strain

E90a; Amp located on $\operatorname{Tn} A$

pBR322 Ampr Tet $^{r}$

Multicopy vector plasmid

Recombinant plasmid; pBR322

pCS100 Amp ${ }^{r} \mathrm{Tet}^{5}, \mathrm{CS}^{-} \mathrm{CS}^{-} \mathrm{CS}^{+}, \mathrm{ST}^{-}$

with HindIII DNA insert

from pCS001

Boylan \& Smyth (1985)

Bolivar et al. (1977)

Boylan et al. (1987)

- Azi, sodium azide; Rif, rifampicin; LT, heat-labile enterotoxin; ST, heat-stable enterotoxin; Amp, ampicillin; Tet, tetracycline; $r$, resistant; s, sensitive; CS-Fim ${ }^{-}$, CS-fimbriae-negative phenotype; CS1, CS1 fimbriae; CS2, CS2 fimbriae; CS3, CS3 fimbriae.

(1970). A small-scale procedure was used to screen large numbers of recombinant plasmids (Coleman \& Foster, 1981). Following digestion by restriction endonucleases, DNA fragments were separated by gel electrophoresis through $0.8 \%$ or $1 \%(\mathrm{w} / \mathrm{v})$ agarose as described by Meyers et al. (1976). For restriction endonuclease mapping of plasmid pCS200, 3\% (w/v) acrylamide gels were used to separate DNA fragments. The restriction endonuclease map was generated by computation using a Cubic Spline Algorithm program written and kindly provided to us by Dr T. Lott (Gouth \& Gouth, 1984). Molecular mass standards in gels consisted of DNA fragments generated by cleavage of bacteriophage $\lambda$ DNA with BamHI and EcoRI restriction endonucleases (Old \& Primrose, 1985) or $1 \mathrm{kbp}$ ladder standards purchased from BRL.

Construction of chimaeric plasmids. Purified plasmid pCS001 DNA was partially digested with HindIII. The resulting fragments were ligated to HindIII-cleaved pBR322 DNA that had been treated with alkaline phosphatase and the recombinant plasmids were transformed into $E$. coli strain $\mathrm{C} 600$ by the $\mathrm{CaCl}_{2}$ method of Cohen et al. (1972). Cells harbouring recombinant plasmids were identified by screening ampicillin-resistant $\left(A \mathrm{mp} \mathrm{p}^{\mathrm{r}}\right)$ transformants for tetracycline sensitivity $\left(\mathrm{Tet}^{\mathrm{s}}\right)$ by replica plating.

Characterization of chimaeric plasmids. Transformants of strain C600 (K12) were chosen which differed in the recombinant plasmid which they harboured. To mobilize their chimaeric plasmids into rifampicin-resistant $\left(\operatorname{Rif}^{r}\right)$ mutants of CS-Fim ${ }^{-}$ETEC, the conjugative plasmid R64, which encodes tetracycline resistance (Tet ${ }^{\mathrm{r}}$ ), and plasmid ColK were first introduced into each of these transformants by mating with strain $\mathrm{C} 600$ carrying plasmids R64 and ColK (Dougan et al., 1978). Transconjugants were selected for a Amp ${ }^{r}$ Tet $^{\mathrm{r}}$ phenotype and tested for colicin production (Frédéricq, 1957). Amp ${ }^{\mathrm{r}} \mathrm{Tet}^{\mathrm{r}} \mathrm{ColK}^{+}$transconjugants were subsequently mated with either the ETEC-derived variant C921b-2 (Rifr) or C91f-6 (Rif ${ }^{r}$ ). Rif ${ }^{r}{ }^{\prime}$ Amp $^{r}$ transconjugants from this second mating were tested for expression of CS1 and CS2 fimbrial antigens by several methods described below.

Detection of CS fimbrial antigens. Antiserum to each of the three CS fimbrial antigens was prepared as already described (Smyth, 1982, 1984). A heat-shock extraction procedure was used to remove CS antigens from the surface of bacterial cell suspensions (Smyth, 1982, 1984). These crude preparations of CS fimbrial antigens were analysed in double immunodiffusion tests (Smyth, 1982), sodium dodecyl sulphate-polyacrylamide gel electrophoresis (SDS-PAGE; Laemmli, 1970) and Western immunoblotting (Burnette, 1982). Other methods used to detect CS fimbrial antigens were slide agglutination, colony immunoblotting and a whole-cell ELISA (Smyth, 1982; Voller et al., 1980; Russell et al., 1985; Boylan et al., 1987). Haemagglutination tests with washed bovine erythrocytes were done in the presence and absence of D-mannose as described by Smyth (1982), using glass slides.

Enterotoxin tests. Heat-stable enterotoxin production was determined in heat-treated $\left(80^{\circ} \mathrm{C}, 10 \mathrm{~min}\right)$ 
supernatant fractions of overnight Casamino acid/yeast extract broth cultures by the suckling infant mouse assay using intragastric inoculation (Giannella, 1976; Olsson \& Söderlind, 1980). Tests for heat-labile enterotoxin were not performed. Appropriate positive and negative controls were included with each batch of assays.

Southern hybridization with a mixed oligonucleotide DNA probe. Plasmid DNA samples were digested with restriction endonucleases, fractionated in $1.0 \%(\mathrm{w} / \mathrm{v})$ agarose gels and transferred to nitrocellulose as described by Maniatis et al. (1982). A 14-mer mixed oligonucleotide (5'-GA[G,A]-AA[G,A]-AA[C,T]-AT[C,T]-A(C)-3'), which was kindly supplied by Dr W. Dallas (Wellcome Biotechnology, USA), was used as probe DNA. This oligonucleotide was synthesized on the basis of the $\mathrm{N}$-terminal amino acid sequence data of the CS2 fimbrial subunit (Klemm et al., 1985). The 5'-ends of $100 \mathrm{pmol}$ of oligonucleotide were labelled with [ $\gamma^{-32}$ P]ATP according to Maniatis et al. (1982). Following the labelling reaction, unincorporated [ $\left.\gamma^{-32} \mathrm{P}\right] \mathrm{ATP}$ was separated from labelled oligonucleotide by centrifugation through Sephadex G-50 (Maniatis et al., 1982). The hybridization reaction was carried out at $37^{\circ} \mathrm{C}$ for $15 \mathrm{~h}$ in $6 \times$ SSC solution $(0.9 \mathrm{M}-\mathrm{NaCl}$ containing $0.09 \mathrm{M}$-sodium citrate, $\mathrm{pH} 7.0)$ as described by Maniatis et al. (1982). After hybridization, the filter was washed twice for $15 \mathrm{~min}$ in $6 \times$ SSC solution at $4{ }^{\circ} \mathrm{C}$. The third wash was performed at room temperature for $10 \mathrm{~min}$ using $6 \times \mathrm{SSC}$ solution.

Analysis of plasmid-encoded polypeptides in minicells. Plasmids were transformed into the minicell-producing $E$. coli strain DS410 by the method of Cohen et al. (1972). Minicells were purified and labelled with [ ${ }^{35}$ S] methionine for the analysis of plasmid-encoded polypeptides according to Dougan \& Kehoe (1984).

\section{RESULTS}

\section{Molecular cloning of CS1-and CS2-fimbrial-antigen-associated determinants}

In the initial approach to molecular cloning of determinants associated with expression of $\mathrm{CS} 1$ and CS2 fimbriae, $24 \mathrm{Amp}^{\mathrm{r}} \mathrm{Tet}^{\mathrm{s}}$ transformants of strain $\mathrm{C600}$ were picked at random. These K12 transformants were tested for production of CS1 and CS2 fimbrial antigens and found to be negative. When the 24 chimaeric plasmids harboured within these transformants were digested with HindIII or EcoRI restriction endonuclease, seven different restriction digest patterns were found. Transformants harbouring chimaeric plasmids representative of each of these restriction endonuclease digest patterns were further examined.

To facilitate mobilization of the chimaeric plasmids into CS-Fim ${ }^{-}$derivatives of wild-type ETEC, i.e. strains C921 b-2 and C91f-6, plasmids R64 and ColK were introduced into each of the seven representative transformants chosen. One recombinant plasmid, termed pCS200, mediated expression of a CS1-fimbrial-antigen-positive phenotype when introduced into strain C921 b-2 and a CS2-fimbrial-antigen-positive phenotype when introduced into strain C91f-6, i.e. pCS200 encoded the information required for expression of either CS1 or CS2 fimbrial antigen in the appropriate host biotype. In the case of both recipients C921b-2 and C91f-6, the CS1 and CS2 fimbrial antigens were never expressed together in any of the 40-50 transconjugant colonies screened from each host. HindIII digestion of pCS200 revealed that the DNA insert consisted of two fragments of $4.7 \mathrm{kbp}$ and $0.8 \mathrm{kbp}$, whereas FcoRI digestion linearized the chimaeric plasmid $(9.8 \mathrm{kbp})$, indicating the absence of EcoRI restriction sites in the cloned DNA sequences. Of the 24 original chimaeric plasmids examined, three others gave identical HindIII and EcoRI restriction endonuclease digest patterns, respectively, to pCS200. However, these three plasmids were not mobilized into wild-ty pe recipients to test for expression of CS fimbrial antigens.

A subsequent screen for recombinant plasmids associated with production of CS1 and CS2 fimbrial antigens was performed using a slightly different approach. In this case, $34 \mathrm{Amp}^{\mathrm{r}} \mathrm{Tet}^{\mathrm{s}}$ transformants were picked at random and plasmids R64 and ColK were introduced into each of these without first screening the recombinant plasmids carried by these transformants by restriction endonuclease analysis. These 34 transformants were each mated with the CS-Fimwild-type strains C921b-2 and C91f-6 and three to five transconjugants from each mating were screened for CS1 and CS2 fimbrial antigen production. Out of the 34 chimaeric plasmids harboured by the transformants, eight were obtained which mediated expression of CS1 and $\mathrm{CS} 2$ fimbrial antigens in the appropriate host backgrounds. These additional eight $\mathrm{CS}^{+} / \mathrm{CS}^{+}-$ associated plasmids identified without prior restriction endonuclease analysis were each found to contain DNA inserts composed of two HindIII fragments identical in size to those of pCS200. 

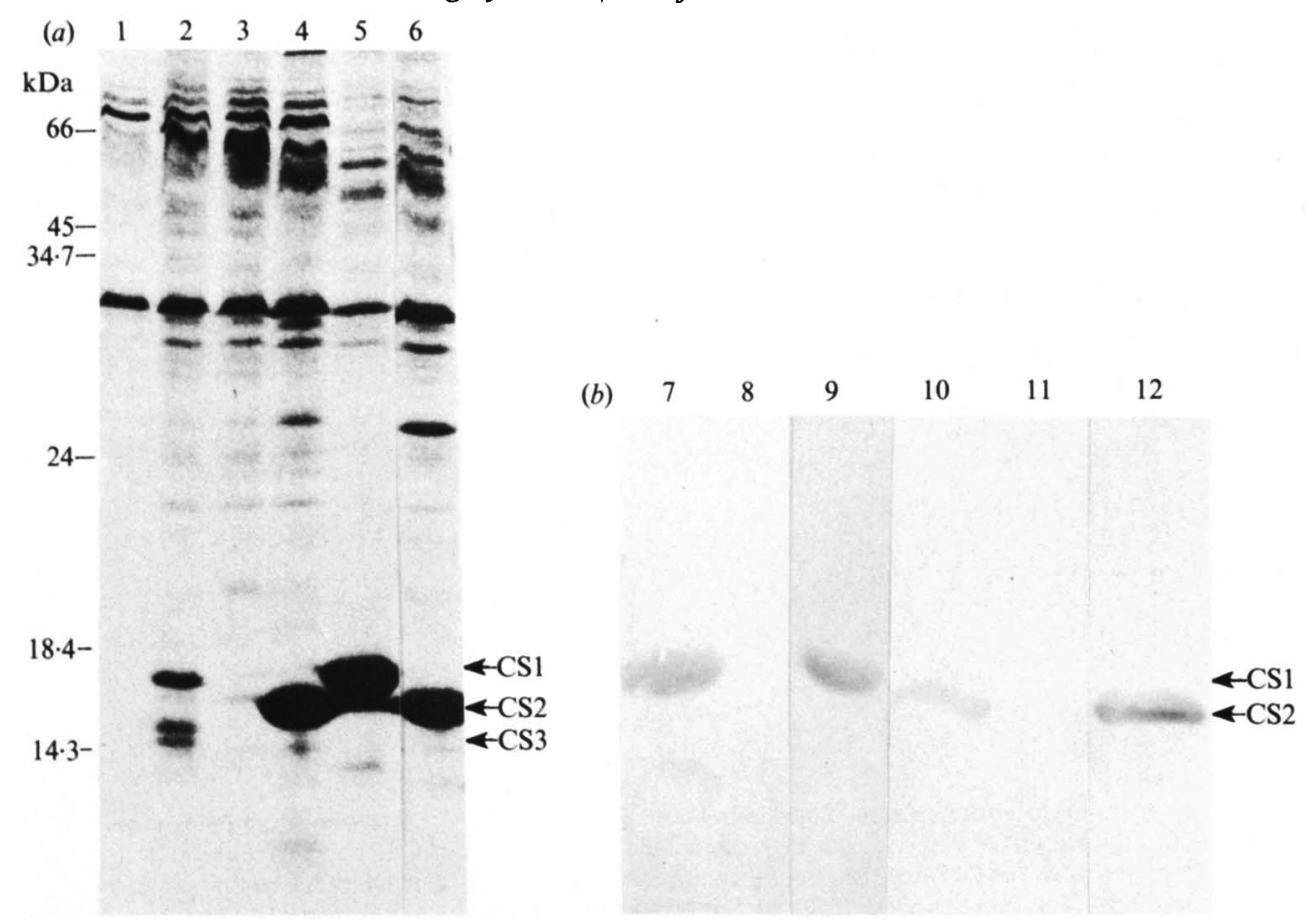

Fig. 1. SDS-PAGE and Western immunoblotting of heat-released extracts of wild-type CS-Fim ${ }^{+}$ ETEC of serotype O6:K15:H16 and of their CS-Fim ${ }^{-}$derivatives harbouring chimaeric plasmid pCS200. Heat-released extracts of CFA-agar-grown cells were prepared as described in Methods. SDSPAGE was performed in $15 \%(\mathrm{w} / \mathrm{v})$ polyacrylamide separating gels and polypeptides were transferred to nitrocellulose by electroblotting. (a) SDS-PAGE polypeptide profiles stained with Coomassie brilliant blue; (b) Western immunoblots. Lanes 1 and $8, \mathrm{CS}-\mathrm{Fim}^{-}$derivative C921 b-2 $\left(\mathrm{CS}^{-} \mathrm{CS}^{-}\right)$; Lanes 2 and 7, wild-type enterotoxigenic strain C921b-1 (CS1 $\left.{ }^{+} \mathrm{CS}^{+}\right)$; lanes 3 and $11, \mathrm{CS}^{-\mathrm{Fim}^{-}}$ derivative $\mathrm{C} 91 \mathrm{f}-6\left(\mathrm{CS} 2^{-}\right)$; lanes 4 and 10 , wild-type enterotoxigenic strain C91f (CS2 ${ }^{+}$only); lanes 5 and 9, strain C921b-2 harbouring plasmid pCS200; lanes 6 and 12, strain C91f-6 harbouring pCS200. Nitrocellulose filters in lanes 7 to 9 were treated with CS1-specific immunoglobulins. Nitrocellulose filters in lanes 10 to 12 were treated with CS2-specific immunoglobulins. The molecular masses of standard proteins are indicated on the left. The polypeptides corresponding to CS1, CS2 and CS3 fimbrial subunits are arrowed, as are the positions of polypeptides which reacted with the antisera. The doublet band in lane 2 is due to the CS3 fimbrial antigen (Levine et al., 1984). Slight lateral diffusion of the CS2 band in lane 4 accounts for the presence of an apparent second polypeptide band below the CS1 band in lane 5 in $(a)$.

\section{Characterization of CS fimbrial antigens produced by strains containing chimaeric plasmid pCS200}

In double immunodiffusion analysis, an extract of strain C921b-2(pCS200) gave rise to a single precipitin line when tested against CS1-specific antiserum. This precipitin line showed a reaction of complete identity with that formed by an extract prepared from the wild-type enterotoxigenic strain $\mathrm{C} 921 \mathrm{~b}-1\left(\mathrm{CS}_{1}{ }^{+} \mathrm{CS}_{3}{ }^{+}\right)$. An extract prepared from strain $\mathrm{C} 91 \mathrm{f}-6$ (pCS200) gave a single precipitin line when analysed against CS2-specific antiserum. This precipitin line fused in a reaction of complete identity with that obtained with control extracts of CS2 antigen from wild-type ETEC. No precipitin lines attributable to the presence of CS3 antigen were found when any of the extracts made from strains currying pCS200 were tested against CS3specific antiserum simultaneously with control extrac is containing CS3 antigen from wild-type ETEC or from strain C600 bearing the wild-type plusnid pCS001.

Surface extracts were also analysed by SDS-PACil ..nd Western immunoblotting (Fig. 1). Extracts prepared from strain C921b-2(pCS200) and from a wild-type CS $1+$ ETEC strain contained a polypeptide which reacted with CSI-specific antiserum and which corresponded in 


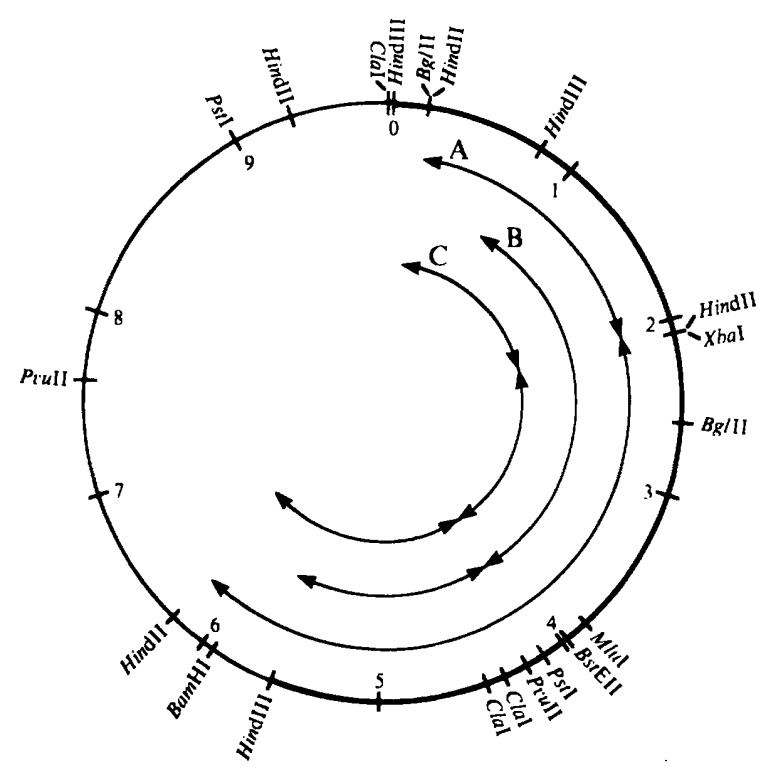

Fig. 2. Restriction endonuclease cleavage site map of the DNA insert in the chimaeric plasmid pCS200. Plasmid pCS200 encodes determinants for the expression of CS1 and CS2 fimbrial antigens. The thin line indicates DNA of the cloning vector plasmid pBR322. The emphasized line indicates the $5.5 \mathrm{kbp}$ DNA fragment cloned from pCS001 into the HindIII site of pBR322. The restriction endonuclease cleavage sites are indicated by tangential lines labelled with the appropriate enzymes. Kilobase-pair markers are indicated clockwise on the cleavage map with the HindIII site of pBR322 as the origin. pCS200 DNA fragments generated by HindII (A), PstI and HindIII (B) and PstI and HindII (C) digestion which hybridized with the mixed oligonucleotide probe for the $\mathrm{N}$-terminus sequences of the gene encoding the structural subunit of CS2 fimbriae are indicated (see Fig. 3).

molecular mass to that reported for the CS1 fimbrial subunit, i.e. 16.3 kDa (Smyth, 1982, 1984; Levine et al., 1984). Western immunoblotting of extracts made from cell suspensions of strain C91f-6(pCS200) and of ETEC strain C91f, a wild-type CS2+-only strain, detected a polypeptide which reacted with CS2-specific antiserum and also corresponded in molecular mass to that reported for the CS2 fimbrial subunit, i.e. 15.3 kDa (Smyth, 1982, 1984).

To see whether the property of haemagglutination was conferred on strains containing the chimaeric plasmid pCS200, strains C921b-2(pCS200) and C91f-6(pCS200), which were expressing the CS1 and CS2 fimbrial antigens, respectively, were examined for adherence to red blood cells in the presence of mannose. Mannose prevents adherence mediated by type 1 or common type fimbriae which are present on many $E$. coli strains. Both strains caused mannoseresistant haemagglutination whereas the corresponding plasmidless recipients used as controls did not, indicating that the chimaeric plasmid mediated production of the respective adhesins as well as the fimbrial antigens.

Two K12 strains (C600 and ED2030) and both CS-Fim- ETEC variants (C91f-6 and C921b-2) bearing plasmid pCS200 were tested for ST enterotoxin. None was produced by these strains.

Physical mapping of the cloned DNA insert of plasmid pCS200 and probing for the gene encoding the structural subunit of CS2 fimbriae

A restriction endonuclease cleavage map of the chimaeric plasmid pCS200 was constructed (Fig. 2).

A mixed oligonucleotide synthesized on the basis of the published $\mathrm{N}$-terminal amino acid sequence data of the CS2 fimbrial subunit (Klemm et al., 1985) was ${ }^{32} \mathrm{P}$-end-labelled and used to probe the chimaeric plasmid pCS200 in Southern blot hybridization experiments. The oligonucleotide mixture hybridized to the $4.7 \mathrm{kbp}$ HindIII fragment of pCS200 [Figs 2 and 3 


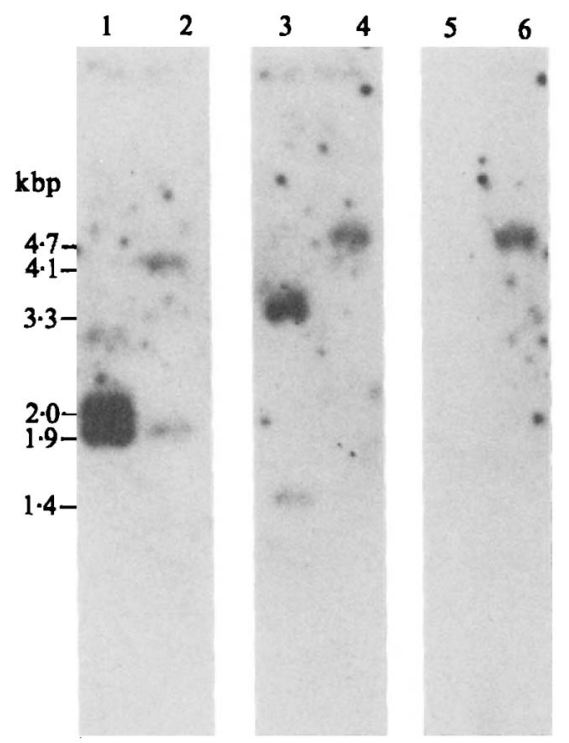

Fig. 3. Southern hybridization analysis of restriction enzyme digest fragments of plasmid DNA using the mixed oligonucleotide DNA probe for the $\mathbf{N}$-terminus sequences of the gene encoding the structural subunit of CS2 fimbriae. The 14-mer mixed oligonucleotide was end-labelled with $\left[\gamma_{-}{ }^{32} \mathbf{P}\right]$ ATP. After restriction endonuclease digestion, plasmid DNA samples were electrophoresed through $1 \%(w / v)$ agarose and DNA fragments transferred to nitrocellulose filters. Lanes: 1, PstI- and HindII-digested pCS200; 2, HindII-digested pCS200; 3, PstI- and HindIII-digested pCS200; 4, HindIII-digested pCS200; 5, HindIII-digested pCS100; 6, HindIII-digested pCS001.

(lane 4)], but not to the $0.8 \mathrm{kbp}$ HindIII fragment. Under conditions of high stringency $\left(68^{\circ} \mathrm{C}\right.$, $2 \times$ SSC, $2 \mathrm{~h}$, and washes with $2 \times$ and $1 \times$ SSC, $10 \mathrm{~min}$ ), no hybridization was obtained (data not shown). No homology was observed with HindIII digests of pCS100, a pBR322 chimaeric plasmid associated with expression of CS3 fimbriae (Boylan et al., 1987; Fig. 3), or of vector plasmid pBR322 (data not shown). The oligonucleotide probe did not hybridize with a HindIII digest of chromosomal DNA of strain C91 $\mathrm{f}-6$, the CS-Fim- plasmid-free derivative used as a recipient for pCS200 in which CS2 fimbriae can be expressed (data not shown).

Other restriction endonuclease digests of pCS200 were used in an attempt to further localize the gene for the structural subunit of the CS2 fimbrial antigen. When pCS200 was digested with both PstI and HindII, two fragments, of $2.0 \mathrm{kbp}$ and $1.9 \mathrm{kbp}$, respectively, showed homology with the oligonucleotide probe (Fig. 3). Two fragments of $1.9 \mathrm{kbp}$ and one of $2.0 \mathrm{kbp}$ are generated from pCS200 by this combination of restriction enzymes (Fig. 2). Two fragments, of $4.1 \mathrm{kbp}$ and $1.9 \mathrm{kbp}$, respectively, from a HindII digest of pCS200 showed homology. Fragments of $3.3 \mathrm{kbp}$ and $1.4 \mathrm{kbp}$ from a Pst I and HindIII double digest of pCS200 also hybridized with the oligonucleotide probe (Fig. 3). The probe hybridized with a $4.7 \mathrm{kbp}$ fragment of a HindIII digest of the parent plasmid pCS001 (Fig. 3).

\section{Analysis of pCS200-encoded polypeptides in E. coli minicells}

Apart from polypeptides encoded by vector plasmid pBR322, no other ${ }^{35} \mathrm{~S}$-labelled polypeptides were expressed in the minicell-producing strain DS410 harbouring the CS-antigenassociated recombinant plasmid pCS200. Neither were stained polypeptides corresponding in molecular mass to the CS1 and CS2 fimbrial subunits seen in stained SDS-PAGE gels of minicells harbouring plasmid pCS200, nor was CS1 or CS2 fimbrial antigen detected in extracts of such minicells by double immunodiffusion. 


\section{DISCUSSION}

Previous work has shown that plasmid pCS001 isolated from a wild-type ETEC strain was associated with the expression of CS1, CS2 and CS3 fimbriae depending on the host harbouring this plasmid (Boylan \& Smyth, 1985) and that the gene encoding the structural subunit of CS3 fimbriae was located on this plasmid (Boylan et al., 1987). The present study reports the molecular cloning of a pCS001-derived DNA fragment which gave rise to expression of CS1 and CS2 fimbriae. This DNA fragment, when cloned into the multicopy vector plasmid pBR322, appeared, like pCS001, to be dependent on the host serotype and biotype for its expression, i.e. the cloning procedure did not remove the constraints on expression of the CS1 or CS2 fimbrial antigen in K12 strains and appropriate wild-type strains of serotype O6:K15:H16 or H(Smyth, 1986).

To date, all wild-type strains expressing CS1 fimbriae have also been found to produce CS3 fimbriae (Smyth, 1986). By molecular cloning, a strain producing only CSl fimbrial antigen has been constructed, viz. strain C921 b-2 harbouring plasmid pCS200. This strain has already proved to be useful for the purification of CS1 fimbriae (H. Matthews \& C. J. Smyth, unpublished data) and should enable investigation of the role of CS1 fimbriae in vivo. A strain producing only CS1 fimbriae has only been previously obtained by transposon-insertion inactivation of the CS3 fimbrial determinant of a CS-fimbriae-associated plasmid followed by mobilization of the mutated plasmid into a CS-Fim ${ }^{-}$derivative of an O6:K15:H16 strain of biotype A (McConnell et al., 1985, 1987).

Several explanations, which are all in accordance with known data, have been proposed to explain the host-specific expression of CS1 and CS2 fimbriae (Smyth, 1986; Boylan, 1987). These include (i) that a plasmid-encoded factor controls chromosomally located genes for fimbrial biogenesis, (ii) that the genes for fimbrial biogenesis are plasmid-encoded but are controlled by chromosomal determinants, (iii) that the genes for the structural subunits are plasmid-located whereas genes encoding ancillary proteins required for fimbrial biogenesis are chromosomally located or vice versa, or (iv) that a site-specific inversion of DNA segments, either plasmid or chromosomally located, occurs in a manner analogous to that controlling flagellar phase variation in Salmonella (Simon et al., 1980; Iino \& Kutsukake, 1983) or type 1 fimbrial variation in E. coli (Abraham et al., 1985; Eisenstein, 1987). Thus, for future investigation of factors which might affect expression of CS1 and CS2 fimbriae, establishing the location of genetic determinants encoding their structural subunits appears essential.

This communication presents evidence for the plasmid location of the determinant encoding the structural subunit of CS2 fimbriae. Plasmids pCS001 and pCS200 hybridized with the mixed oligonucleotide probe synthesized on the basis of the published $\mathrm{N}$-terminal amino acid sequence of the CS2 fimbrial subunit (Klemm et al., 1985). This finding shows that the CS2-fimbriaenegative phenotype found when these plasmids are present in hosts other than serotype $\mathrm{O} 6: \mathrm{K} 15: \mathrm{H} 16$ strains of biotypes $\mathrm{B}, \mathrm{C}$ or $\mathrm{F}$ is not due simply to the absence of the gene encoding the CS2 structural subunit.

The mixed oligonucleotide probe for the $\mathrm{N}$-terminus sequence of the gene encoding the structural subunit of CS2 fimbriae hybridized to restriction endonuclease fragments which encompassed most of the DNA insert of plasmid pCS200 (Figs 2 and 3), i.e. the $4.7 \mathrm{kbp} \mathrm{HindIII}$ fragment. It thus seems possible that the probe is not entirely specific for the CS2 subunit gene. Since the amino acid analyses of the CS1 and CS2 subunit proteins appear to be very similar $(\mathrm{H}$. Matthews \& C. J. Smyth, unpublished data), the two subunit proteins may share some degree of $\mathrm{N}$-terminal homology. Therefore, if a CS1 subunit gene is also located on pCS200, the possibility exists that the probe hybridized with this gene as well as the CS2 subunit gene. In addition, the probe may have hybridized to a gene or genes encoding minor fimbrial proteins sharing homologous sequences with the CS2 subunit gene. Another explanation could be the repetition of CS2 sequences within the cloned DNA fragment.

The absence of CS1 or CS2 expression in hosts other than those of serotype O6:K15:H16 or $\mathrm{H}$ - or in hosts of this serotype and appropriate biotype, respectively, may be due to the lack of a positive controlling element or to the presence of a negative controlling element (Smyth, 1986; Boylan, 1987). Alternatively, the possibility exists that the CS1 or CS2 subunit protein is 
produced, but is unstable in certain hosts and is degraded rapidly, thereby yielding a CS1- or CS2-negative phenotype, respectively, or a doubly negative phenotype. Minicells prepared from $E$. coli strain DS410 containing pCS200 were used in an attempt to examine whether CSfimbriae-associated polypeptides were expressed, but only vector-encoded polypeptides were detected. Furthermore, when E. coli strain K12 carrying pCS200 was examined for the intracellular presence of CS1 or CS2 subunit proteins neither was detected by Western immunoblotting (M. Boylan, unpublished data). Thus, these observations suggest (i) the involvement of chromosomal function(s) or (ii) post-transcriptional regulation or posttranslational modification.

The determinants required for the biogenesis of many fimbriae are distinct from determinants required for the expression of adhesive functions such as haemagglutination associated with these organelles (Maurer \& Orndorff, 1985; Hacker et al., 1985; van Die et al., 1986; de Graaf \& Mooi, 1986; Lindberg et al., 1986; 1987; Minion et al., 1986; Normark et al., 1986; Rhen et al., 1986). We have shown that appropriate wild-type strains containing pCS200 cause mannoseresistant haemagglutination of bovine erythrocytes. Therefore, the cloned DNA fragment in pCS200 carries the information needed for adhesin production in relation to both CS1 and CS2 fimbriae. However, it remains to be shown whether or not the adhesins are minor components of the assembled CS1 and CS2 fimbrial structures as in the case of P-fimbriae (Normark et al., 1986; Lindberg et al., 1986, 1987).

Addendum. Willshaw et al. (1988) have reported cloning of the determinants for expression of CS1, CS2 and CS3 fimbriae together on a $17 \mathrm{kbp}$ fragment of HindIII-digested plasmid DNA. These determinants were not closely linked to those for ST and LT enterotoxin production. Moreover, expression of CS1 and CS2 fimbriae was associated with a $10 \mathrm{kbp}$ subclone comprising three HindIII fragments of approximately $0 \cdot 8,4.9$ and $4 \cdot 3 \mathrm{kbp}$. Neither CS1 nor CS2 fimbrial antigen was expressed in K12 strains.

M. B. was in receipt of a research studentship and D.C. was the holder of a research fellowship from the Medical Research Council of Ireland. J.R.S. gratefully acknowledges the expert technical assistance of L. Coffield. We thank Dr T. Lott for writing the Cubic Spline Algorithm program and Dr W. Dallas for kindly preparing the 14mer oligonucleotide probe. This research was supported by a grant from the MRCI and a grant-in-aid from Coralab Research, Cambridge, UK, to C. J.S. and by Biomedical Research Support Grant RR05364 from the US National Institutes of Health to J.R.S. at Emory University.

\section{REFERENCES}

Abraham, J. M., Freitag, C. S., Clements, J. R. \& EISENSTEIN, B. I. (1985). An invertible element of DNA controls phase variation of type 1 fimbriae of Escherichia coli. Proceedings of the National Academy of Sciences of the United States of America 82, 57245727.

ApPleyard, R. K. (1954). Segregation of new lysogenic types during growth of a doubly lysogenic strain derived from Escherichia coli K12. Genetics 39, 440-452.

Bolivar, F., Rodriguez, R. L., Greene, P. J., Betlach, M. C., Heyneker, H. L. \& Boyer, H. W. (1977). Construction and characterization of new cloning vectors. II. A multipurpose cloning system. Gene 2, 95-113.

Boylan, M. H. (1987). Genetic analysis of CS1, CS2 and CS3 fimbriae of enterotoxigenic Escherichia coli. $\mathrm{PhD}$ thesis, Trinity College, University of Dublin.

BoyLAN, M. \& SMYTH, C. J. (1985). Mobilization of CS fimbriae-associated plasmids of enterotoxigenic Escherichia coli of serotype $06: \mathrm{K} 15: \mathrm{H} 16$ or $\mathrm{H}$-into various wild-type hosts. FEMS Microbiology Letters 29, 83-89.
Boylan, M., Coleman, D. C. \& Smyth, C. J. (1987). Molecular cloning and characterization of the genetic determinant encoding CS3 fimbriae of enterotoxigenic Escherichia coli. Microbial Pathogenesis 2, 195-209.

BURNETTE, W. N. (1982). 'Western blotting' : electrophoretic transfer of proteins from sodium dodecyl sulfate-polyacrylamide gels to unmodified nitrocellulose and radiographic detection with antibody and radioiodinated Protein A. Analytical Biochemistry 112, 195-203.

Clewell, D. B. \& Helinski, D. R. (1970). Properties of a supercoiled deoxyribonucleic acid-protein relaxation complex and strand specificity of the relaxation event. Biochemistry 9, 4428-4440.

Cohen, S. N., Chang, A. C. Y. \& Hsu, L. (1972). Nonchromosomal antibiotic resistance in bacteria : genetic transformation of Escherichia coli by R-factor DNA. Proceedings of the National Academy of Sciences of the United States of America 69, 21102114.

Coleman, D. C. \& Foster, T. J. (1981). Analysis of the reduction in expression of tetracycline resistance 
determined by transposon $\operatorname{Tn} 10$ in the multicopy state. Molecular and General Genetics 182, 171177.

Cravioto, A., Scotland, S. M. \& Rowe, B. (1982). Hemagglutination activity and colonization factor antigens I and II in enterotoxigenic and nonenterotoxigenic strains of Escherichia coli isolated from humans. Infection and Immunity 36, 189-197.

van Die, I., Zuidweg, E., Hoekstra, W. \& BergMANS, H. (1986). The role of fimbriae of uropathogenic Escherichia coli as carriers of the adhesin involved in mannose resistant haemagglutination. Microbial Pathogenesis 1, 51-56.

Dougan, G. \& KeHOE, M. (1984). The minicell system as a method for studying expression of plasmid DNA. Methods in Microbiology 17, 233-258.

Dougan, G. \& Sherratt, D. (1977). The transposon $\mathrm{Tn} l$ as a probe for studying ColEl structure and function. Molecular and General Genetics 151, 151160.

Dougan, G., Crosa, J. H. \& Falkow, S. (1978). Mobilization of the Escherichia coli plasmid ColE1 (colicin E1) and ColEl vectors used in recombinant DNA experiments. Journal of Infectious Diseases 137, 676-680.

Duguid, J. P. \& OLD, D. C. (1980). Adhesive properties of Enterobacteriaceae. In Bacterial Adherence, Receptors and Recognition Series B, vol. 6, pp. 185-217. Edited by E. H. Beachey. London: Chapman \& Hall.

Echeverria, P., Seriwatana, J., Taylor, D. N., Changchawalit, S., Smyth, C. J., Twohig, J. \& Rowe, B. (1986). Plasmids coding for colonization factor antigens I and II, LT and ST-A2 in Escherichia coli. Infection and Immunity 51, 626-630.

EISENSTEIN, B. I. (1987). Fimbriae. In Escherichia coli and Salmonella typhimurium: Cellular and Molecular Biology, vol. 1, pp. 84-90. Edited by F. C. Neidhardt. Washington, DC: American Society for Microbiology.

Eisenstein, B. I. \& ENGleberg, N. C. (1986). Applied molecular genetics: new tools for microbiologists and clinicians. Journal of Infectious Diseases 153, 416-429.

Evans, D. G. \& Evans, D. J., JR (1978). New surfaceassociated heat-labile colonization factor antigen (CFA/II) produced by enterotoxigenic Escherichia coli of serogroups $\mathrm{O} 6$ and O8. Infection and Immunity 21, 638-647.

Evans, D. G., Evans, D. J. \& TJOA, W. (1977). Hemagglutination of human group A erythrocytes by enterotoxigenic Escherichia coli isolated from adults with diarrhea: correlation with colonization factor. Infection and Immunity 18, 330-337.

FOSTER, T. J. \& WILleTTS, N. S. (1976). Genetic analysis of deletions of R100-1 that are both transferdeficient and tetracycline-sensitive. Journal of General Microbiology 93, 133-140.

FrédéricQ, P. (1957). Colicins. Annual Review of Microbiology 11, 7-22.

Giannella, R. A. (1976). Suckling mouse model for detection of heat-stable Escherichia coli enterotoxin: characteristics of the model. Infection and Immunity 14, 95-99.

GouTh, E. J. \& Gouth, N. M. (1984). Direct calculation of the sizes of DNA fragments separated by gel electrophoresis using programmes written for a pocket calculator. Nucleic Acids Research 12, 845853.

DE GraAF, F. K. \& MooI, F. R. (1986). The fimbrial adhesins of Escherichia coli. Advances in Microbial Physiology 28, 65-143.

HACKer, J., Schmidt, G., Hughes, C., KNAPP, S., Marget, M. \& Goebel, W. (1985). Cloning and characterization of genes involved in production of mannose-resistant, neuraminidase-susceptible $(X)$ fimbriae from a uropathogenic O6:K 15:H31 Escherichia coli strain. Infection and Immunity 47, 434-440.

HANSEN, J. B. \& OLsen, R. H. (1978). Isolation of large plasmids and characterization of the $\mathbf{P} 2$ incompatibility group plasmids pMG1 and pMG2. Journal of Bacteriology 135, 227-238.

InNo, T. \& KutsukaKe, K. (1983). Flagellar phase variation in Salmonella : a model system regulated by flip-flop DNA inversions. In Nucleic Acid Research: Future Developments, pp. 395-406. Edited by K. Mizobuchi, I. Watanabe \& J, D. Watson. New York: Academic Press.

JoNES, G. W. \& ISAACSON, R. E. (1984). Proteinaceous bacterial adhesins and their receptors. CRC Critical Reviews in Microbiology 10, 229-260.

KLEMM, P. (1985). Fimbrial adhesins of Escherichia coli. Reviews of Infectious Diseases 7, 321-340.

Klemm, P., GaAstra, W., McConnell, M. M. \& SMITH, H, R. (1985). The CS2 fimbrial antigen from Escherichia coli, purification, characterization and partial covalent structure. FEMS Microbiology Letters 26, 207-210.

LAEMMLI, U. K. (1970). Cleavage of structural proteins during the assembly of the head of bacteriophage $\mathrm{T} 4$. Nature, London 227, 680-685.

LENNOX, E. S. (1955). Transduction of linked genetic characters of the host by bacteriophage P1. Virology 1, 190-206.

LEVINE, M. M. (1987). Escherichia coli that cause diarrhea : enterotoxigenic, enteropathogenic, enteroinvasive, enterohemorrhagic, and enteroadherent. Journal of Infectious Diseases 155, 377-389.

Levine, M. M., Ristaino, P., Marley, G., Smyth, C., Knutton, S., Boedeker, E., BlaCk, R., Young, C., Clements, M. L., Cheney, C. \& Patnaik, R. (1984). Coli surface antigens 1 and 3 of colonization factor antigen II-positive enterotoxigenic Escherichia coli: morphology, purification and immune responses in humans. Infection and Immunity 44, 409-420.

LINDBERG, F., LUND, B. \& Normarx, S. (1986). Gene products specifying adhesion of uropathogenic Escherichia coli are minor components of pili. Proceedings of the National Academy of Sciences of the United States of America 83, 1891-1895.

LINDBERG, F., LUND, B., JOHANSSON, L. \& NoRMARK, S. (1987). Localization of the receptor-binding protein adhesin at the tip of the bacterial pilus. Nature, London 328, 84-87.

Maniatis, T., Fritsch, E. F. \& Sambrook, J. (1982). Molecular Cloning : a Laboratory Manual, pp. 324328, 382-389 and 464-467. Cold Spring Harbor, NY: Cold Spring Harbor Laboratory.

Manning, P. A., Timmis, K. N. \& Stevenson, G. (1985). Colonization factor antigen (CFA/II) of enterotoxigenic Escherichia coli: molecular cloning of the CS3 determinant. Molecular and General Genetics 200, 322-327. 
Maurer, L. \& Orndorff, P. E. (1985). A new locus, pilE, required for the binding of type 1 piliated Escherichia coli to erythrocytes. FEM Microbiology Letters 30, 59-66.

McConnell, M. M., Thomas, L. V., DaY, N. P. \& Rowe, B. (1985). Enzyme-linked immunosorbent assays for the detection of adhesion factor antigens of enterotoxigenic Escherichia coli. Journal of Infectious Diseases 152, 1120-1127.

McConnell, M. M., Mullany, P. \& Rowe, B. (1987). A comparison of the surface hydrophobicity of enterotoxigenic Escherichia coli of human origin producing different adhesion factors. FEMS Microbiology Letters 42, 59-62.

Meyers, J. A., Sanchez, D., Elwell, L. P. \& FALKow, S. (1976). Simple agarose gel electrophoretic method for the identification and characterization of plasmid deoxyribonucleic acid. Journal of Bacteriology 127, 1529-1537.

Minion, F. C., Abraham, S. N., Beachey, E. H. \& GoGueN, J. D. (1986). The genetic determinant of adhesive function in type 1 fimbriae of Escherichia coli is distinct from the gene encoding the fimbrial subunit. Journal of Bacteriology 165, 1033-1036.

Mullany, P., Field, A. M., McConnell, M. M., Scotland, S. M., SMith, H. R. \& Rowe, B. (1983). Expression of plasmids coding for colonization factor antigen II (CFA/II) and enterotoxin production in Escherichia coli. Journal of General Microbiology 129, 3591-3601.

Normark, S., BÅga, M., Göransson, M., LindberG, F. P., LUND, B. \& NorGreN, M. (1986). Genetics and biogenesis of Escherichia coli adhesins. In Microbial Lectins and Agglutinins: Properties and Biological Activity, pp. 113-143. Edited by D. Mirelman. New York: Wiley.

OLD, D. C. (1985). Haemagglutination methods in the study of Escherichia coli. In The Virulence of Escherichia coli: Reviews and Methods, Special Publication of the Society for General Microbiology no. 13, pp. 287-313. Edited by M. Sussman. London: Academic Press.

OLd, R. W. \& Primrose, S. B. (1985). Principles of Gene Manipulation: an Introduction to Genetic Engineering, 3rd edn, pp. 69-70 and 325-338. Oxford: Blackwell Scientific Publications.

OlsSon, E. \& SöDERLIND, O. (1980). Comparison of different assays for definition of heat-stable enterotoxigenicity of Escherichia coli porcine strains. Journal of Clinical Microbiology 11, 6-15.

PARRY, S. H. \& RoOKe, D. M. (1985). Adhesins and colonization factors of Escherichia coli. In The Virulence of Escherichia coli: Reviews and Methods, Special Publication of the Society for General
Microbiology no. 13, pp. 79-155. Edited by $M$. Sussman. London: Academic Press.

Rhen, M., Tenhunen, J., Väisänen-Rhen, V., Pere, A., BÅGA, M. \& Korhonen, T. (1986). Fimbriation and P-antigen recognition of Escherichia coli strains harbouring mutated recombinant plasmids encoding fimbrial adhesins of the uropathogenic $E$. coli strain KS71. Journal of General Microbiology 132, 71-77.

Russell, R. R. B., Coleman, D. \& Dougan, G. (1985). Expression of a gene for glucan-binding protein from Streptococcus mutans in Escherichia coli. Journal of General Microbiology 131, 295-299.

Scotland, S. M., Gross, R. J. \& Rowe, B. (1977). Serotype-related enterotoxigenicity in Escherichia coli O6. H16 and O148. H28. Journal of Hygiene 79, 395-403.

Scotland, S. M., McConnell, M. M., Willshaw, G. A., Rowe, B. \& Field, A. M. (1985). Properties of wild-type strains of enterotoxigenic Escherichia coli which produce colonization factor antigen II and belong to serogroups other than O6. Journal of General Microbiology 131, 2327-2333.

Simon, M., Zieg, J., Silverman, M., Mandel, G. \& DoolitTle, R. (1980). Phase variation: evolution of a controlling element. Science 209, 1370-1374.

Smith, H. R., Scotland, S. M. \& Rowe, B. (1983). Plasmids coding for production of colonization factor antigen II and enterotoxin production in strains of Escherichia coli. Infection and Immunity 40 , 1236-1239.

SMYTH, C. J. (1982). Two mannose-resistant haemagglutinins on enterotoxigenic Escherichia coli of serotype $06: \mathrm{K} 15: \mathrm{H} 16$ or $\mathrm{H}$ - isolated from travellers' and infantile diarrhoea. Journal of General Microbiology 128, 2081-2096.

SMYTH, C. J. (1984). Serologically distinct fimbriae on enterotoxigenic Escherichia coli of serotype O6:K15:H16 or H-. FEMS Microbiology Letters 21, 51-57.

SMYTH, C. J. (1986). Fimbrial variation in Escherichia coli. In Antigenic Variation in Infectious Diseases, Special Publication of the Society for General Microbiology, no. 19, pp. 95-125. Edited by T. H. Birkbeck \& C. W. Penn. Oxford: IRL Press.

Voller, A., Bidwell, D. \& Bartlett, A. (1980). Enzyme-linked immunosorbent assay. In Manual of Clinical Immunology, 2nd edn, pp. 359-371. Edited by N. R. Rose \& H. Friedman. Washington, DC: American Society for Microbiology.

Willshaw, G. A., Smith, H. R., McConnell, M. M. \& Rowe, B. (1988). Cloning of genes encoding colisurface antigens in enterotoxigenic Escherichia coli. FEMS Microbiology Letters 49, 473-478. 